\title{
CNS blockade of acoustic stress-induced gastric motor inhibition by $\kappa$-opiate agonists in dogs
}

\author{
M. GUE, C. HONDE, X. PASCAUD, J. L. JUNIEN, M. ALVINERIE, AND L. BUENO \\ Department of Pharmacology, Institut National de la Recherche Agronomique, 31300 Toulouse; \\ and Jouveinal Laboratoires, 94260 Fresnes, France
}

Gue, M., C. Honde, X. Pascaud, J. L. Junien, M. AlviNERIE, AND I. BuENO. CNS blockade of acoustic stress-induced gastric motor inhibition by $\kappa$-opiate agonists in dogs. Am. J. Physiol. 254 (Gastrointest. Liver Physiol. 17): G802-G807, 1988. - The influence of the $\kappa$-opioid substances dynorphin(1-13), ethylketocyclazocine (EKC), and U 50488 and $\mu$-opioid substance $\left[\mathrm{D}-\mathrm{Ala}^{2}-N\right.$-Me, $p$-nitro- $\mathrm{Phe}^{4}-\mathrm{Gly}^{5}$-ol] enkephalin (DAGO) on gastric motor inhibition induced by acoustic stress (AS) was investigated in fasted dogs with strain-gauge transducers chronically implanted on the antrum and proximal jejunum. AS induced by $1 \mathrm{~h}$ of music (80-90 dB) was delivered through earphones. Starting 40-50 min after the last migrating motor complex (MMC), AS delayed by $114 \%$ the occurrence of the next gastric MMC, whereas intestinal motility was unaffected. During AS plasma cortisol increased $(P<0.05)$ by $215 \%, 15 \mathrm{~min}$ after the beginning of noise and reached a peak at $30 \mathrm{~min}$. When administered intracerebroventricularly at doses higher than $20 \mathrm{ng} / \mathrm{kg}$, dynorphin abolished the ASinduced lengthening of the gastric MMC cycle. Similar blockade was observed for EKC and U 50488 at doses of 10 and/or $20 \mathrm{ng} / \mathrm{kg}$, but DAGO was unable to affect the AS-induced gastric inhibition at any dosage tested $(20-200 \mathrm{ng} / \mathrm{kg} \mathrm{icv})$. At doses effective against AS-induced hypomotility, both dynorphin-(1-13) and EKC reduced significantly $(P \leq 0.05)$ the associated maximal increase in plasma cortisol level. Plasma cortisol was unmodified by intracerebroventricular administration of DAGO. None of the agonists affected basal plasma cortisol levels or the increase $(0-90 \mathrm{~min})$ in response to intravenous adrenocorticotropic hormone (ACTH, $5 \mathrm{IU})$. Both EKC $(50 \mathrm{ng} / \mathrm{kg})$ and U $50488(20 \mathrm{ng} / \mathrm{kg})$ were unable to antagonize the inhibitory effect of ovine corticotropin-releasing factor (CRF, $100 \mathrm{ng} / \mathrm{kg}$ icv). We conclude that $\kappa$ - but not $\mu$-substances act centrally to block the inhibition of gastric motility and the plasma cortisol increase produced by AS. These effects are probably due to a blockade of CRF release rather than to an inactivation of CRF-induced pituitary $\mathrm{ACTH}$ release or to the direct inhibition of cortisol release at adrenal gland level.

opiates; $\kappa$-agonists; gastrointestinal motility

ENDOGENOUS OPIOIDS ARE INVOLVED in responses to many stressors, and exposure to stressful stimuli can produce opiate-like alterations that can be reversed by the opiate antagonist naloxone in both rats (27) and humans (39). Furthermore, some changes in gastrointestinal motility (36) or gastric emptying (38) associated with centrally acting stressful stimuli are reduced by the concomitant infusion of naloxone. Recently we have shown that the gastric motor inhibition induced by acoustic stress (AS) in dogs is blocked by the previous administration of benzodiazepine and the $\gamma$-aminobutyric acid agonist muscimol but not by naloxone (18). In addition, both acoustic and cold-exposure stress in mice are accompanied by increased gastric emptying that is also reversed by diazepam and propranolol but not by naloxone (19). These recent findings support the idea that some effects of stressful stimuli on gastric motility may not be related to activation of opiate pathways at central nervous system (CNS) and/or peripheral levels.

In humans, opioid peptides have been shown to inhibit adrenocorticotropic hormone (ACTH) and cortisol secretion $(11,17,41)$. In contrast, the data obtained in rats are variable; while some groups have reported that opioid peptides stimulate the release of $\mathrm{ACTH}(12,22)$ and corticotropin-releasing factor (CRF)-like bioactivity (4), others found that opioids inhibit $\mathrm{ACTH}$ secretion and that naloxone stimulates $\mathrm{ACTH}$ and corticosterone secretion $(13,31)$. More recently it was demonstrated that opioid peptides, particularly $\kappa$-agonists such as dynorphin, act through specific opioid receptors to inhibit CRF release from the rat hypothalamus $(33,40)$.

The present study was performed in dogs 1 ) to compare the effects of centrally administered $\mu$ - and $\kappa$-agonist peptides on the inhibition of gastric motility and the associated cortisol release induced by acoustic stress and 2) to determine the action of these opioid peptides by testing their ability to influence the ACTH-induced cortisol release and the effects of centrally administered $\mathrm{CRF}$ on gastric motility.

\section{METHODS}

\section{Animal Preparation}

Six adult mongrel dogs weighing 15-18 kg were used for the experiments. Under halothane (Fluothane ND) anesthesia, three strain-gauge transducers prepared according to a method previously described (32) were sewn on the stomach 15 and $7 \mathrm{~cm}$ from the pylorus and on the proximal jejunum, $60 \mathrm{~cm}$ from the ligament of Treitz. In addition, a stainless steel cannula, $19 \mathrm{~mm}$ long, was implanted into the right lateral ventricle of the brain through a hole made on the frontal bone $2 \mathrm{~mm}$ posterior to the bregma and $5 \mathrm{~mm}$ lateral to the sagittal suture; in four animals, a silicone catheter was also inserted into the right jugular vein. At the end of surgery, the free 
ends of the strain-gauge wires and the catheter were brought subcutaneously to the back of the neck, and the animals were allowed to recover $10-15$ days before beginning the experiments. Each day at 1700, the dogs received a standard meal of $600 \mathrm{~g}$ of canned food (Fido-Quaker, France), containing $21.7 \%$ dry matter, $7.7 \%$ protein, $4.5 \%$ fat, $6.9 \%$ carbohydrates, and $2.6 \%$ minerals. Water was available ad libitum.

\section{Motility Recordings}

Gastrointestinal mechanical activity was recorded continuously $23 \mathrm{~h}$ /day by connecting the strain gauges to a four-channel wheatstone-bridge amplifier (Vishay, France) and a potentiometric recorder. Each strain gauge was calibrated before implantation. The transducer was clamped firmly in an horizontal position at the level of the strain gauge, and weights (1-5 g) were attached 1 $\mathrm{mm}$ lateral from the soldering point. The amplitude $(\mathrm{mV})$ was noted, and an average calibration curve was calculated. Before the first recording session, corresponding direct current voltages were applied to calibrate the potentiometric recorder (Rikadenki, Japan).

\section{Experimental Procedure}

The experiments were performed at 2-day intervals and $15 \mathrm{~h}$ after the last meal. In a first series of experiments, 40-50 min after the occurrence of a gastric migrating motor complex (MMC) the animals were subjected to music by earphones (80-90 dB broad frequency noise) for $1 \mathrm{~h}$ according to a procedure previously described (18). In the four animals with jugular catheters, blood samples for plasma cortisol measurements were taken 5 min before and after the beginning of AS and at 15 -min intervals during the next $90 \mathrm{~min}$. AS was preceded ( $10 \mathrm{~min}$ ) by intracerebroventricular administration of sterilized saline (vehicle) or saline containing various concentrations of dynorphin-(1-13) (Sigma, Laverpilliere, France) ethylketocyclazocine (EKC; SterlingWinthrop, Guilford, UK), U 50488 (Upjohn, Kalamazoo, $\mathrm{MI})$, and $\left[\mathrm{D}-\mathrm{Ala}^{2}, N\right.$-Me, $p$-nitro-Phe ${ }^{4}-\mathrm{Gly}^{5}$-ol]enkephalin (DAGO; Sigma, France). These substances were administered at the following dosages (in $\mathrm{ng} / \mathrm{kg}$ ): dynorphin-(1-13), 10-200; EKC, 10-50; U 50488, 20; and DAGO, 20-200. Each treatment was applied twice in each animal and in a randomized order. Dynorphin-(113), EKC, U 50488, and DAGO were also administered alone at the same doses with blood sampling but without AS (control).

In a second series of experiments the same animals also received $5 \mathrm{IU}$ of ACTH (Choay, Paris, France) administered $10 \mathrm{~min}$ after intracerebroventricular injection of dynorphin-(1-13) (100 ng/kg), EKC (20 ng/kg), or vehicle. In a last series of trials, ovine CRF (Sigma, France) was injected intracerebroventricularly at a dose of $100 \mathrm{ng} / \mathrm{kg}, 10 \mathrm{~min}$ after previous administration of EKC (50 ng/kg icv), U 50488 (20 ng/kg icv), or vehicle.

Motor effects were assessed by measuring the duration of gastric and/or jejunal disruption of the MMC pattern. The values are expressed as means $\pm \mathrm{SE}$ and were compared by analysis of variance and Student's $t$ test.

Plasma cortisol was determined by high-performance liquid chromatography after extraction with methylene chloride using a microparticulate silica gel column with ultraviolet detection at $254 \mathrm{~nm}$ and a $2 \mathrm{ng} / \mathrm{ml}$ sensitivity (1).

\section{RESULTS}

\section{Motility Studies}

Effects of acoustic stress. The control antral mechanical activity was characterized by cyclic phases of gastric contractions lasting $28 \pm 9 \mathrm{~min}(n=12)$ and occurring at 1.5 - to 2 -h intervals (Fig. 1). These antral activity fronts or MMC were associated with the occurrence of jejunal motor activity, migrating aborally. The jejunal MMC presented two phases of irregular (phase II) and regular (phase III) activities lasting $39 \pm 11$ and $6.4 \pm$ $0.6 \mathrm{~min}$, respectively. The AS that began $40 \mathrm{~min}$ after the beginning of the last gastric MMC delayed by $114 \%$ the occurrence of the next gastric MMC. However, jejunal MMC continued at a normal frequency (Fig. 1 and Table 1). The time interval between the first and second gastric MMCs after AS was not significantly different $(P>0.05)$ from the control interval. No difference in gastric response was observed between naive and previously tested animals.

Influence of $\kappa$ - vs. $\mu$-agonists. When administered intracerebroventricularly at doses of 10 and $20 \mathrm{ng} / \mathrm{kg}$ in 15-h fasted dogs, dynorphin-(1-13) did not affect significantly $(P>0.05)$ the duration of the gastric MMC cycle. However, a lengthening of the gastric MMC cycle with no change in intestinal motility was observed with a higher dose (Table 1). Similarly, EKC administered intracerebroventricularly at doses higher than $20 \mathrm{ng} / \mathrm{kg}$ also delayed the occurrence of the next gastric MMC. These substances were therefore tested on stress-induced gastric motor changes only at doses inactive per se on the pattern of gastric contractions.

Intracerebroventricular administration of dynorphin(1-13) at a dose of $20 \mathrm{ng} / \mathrm{kg} 10 \mathrm{~min}$ before AS completely abolished the AS-induced lengthening of the gastric MMC cycle (Fig. 1 and Table 1), whereas a significant reduction $(P<0.05)$ was obtained at the lower dose $(10$ $\mathrm{ng} / \mathrm{kg}$ ). Similarly EKC injected intracerebroventricularly (10 and $20 \mathrm{ng} / \mathrm{kg}$ ) and U $50488(20 \mathrm{ng} / \mathrm{kg}$ ) also suppressed the inhibition of gastric contractions induced by AS (Table 1); in contrast, DAGO injected centrally at doses inactive per se $(<200 \mathrm{ng} / \mathrm{kg})$ was unable to modify the AS-induced gastric motor changes (Fig. 1). Given alone at a dose of $200 \mathrm{ng} / \mathrm{kg}$, DAGO delayed the occurrence of gastric MMC and increased the duration of phase II in the jejunum.

Plasma cortisol level and ACTH responsiveness. In the four dogs with jugular vein catheters, the plasma cortisol level, which was $9.6 \pm 2.7 \mathrm{ng} / \mathrm{ml}( \pm \mathrm{SE}, n=8)$ during the control period corresponding to phase I of the gastric MMC, was significantly increased by AS as early as 5 min after the beginning of $\mathrm{AS}(P<0.01)$. It reached a maximal value of $51.8 \pm 8.2 \mathrm{ng} / \mathrm{ml} 25 \mathrm{~min}$ later, and this increase was significant $(P<0.05)$ during at least $45 \mathrm{~min}$ (Fig. 2).

Dynorphin-(1-13) injected intracerebroventricularly at doses of $100 \mathrm{ng} / \mathrm{kg}$ significantly $(P<0.01)$ reduced by 

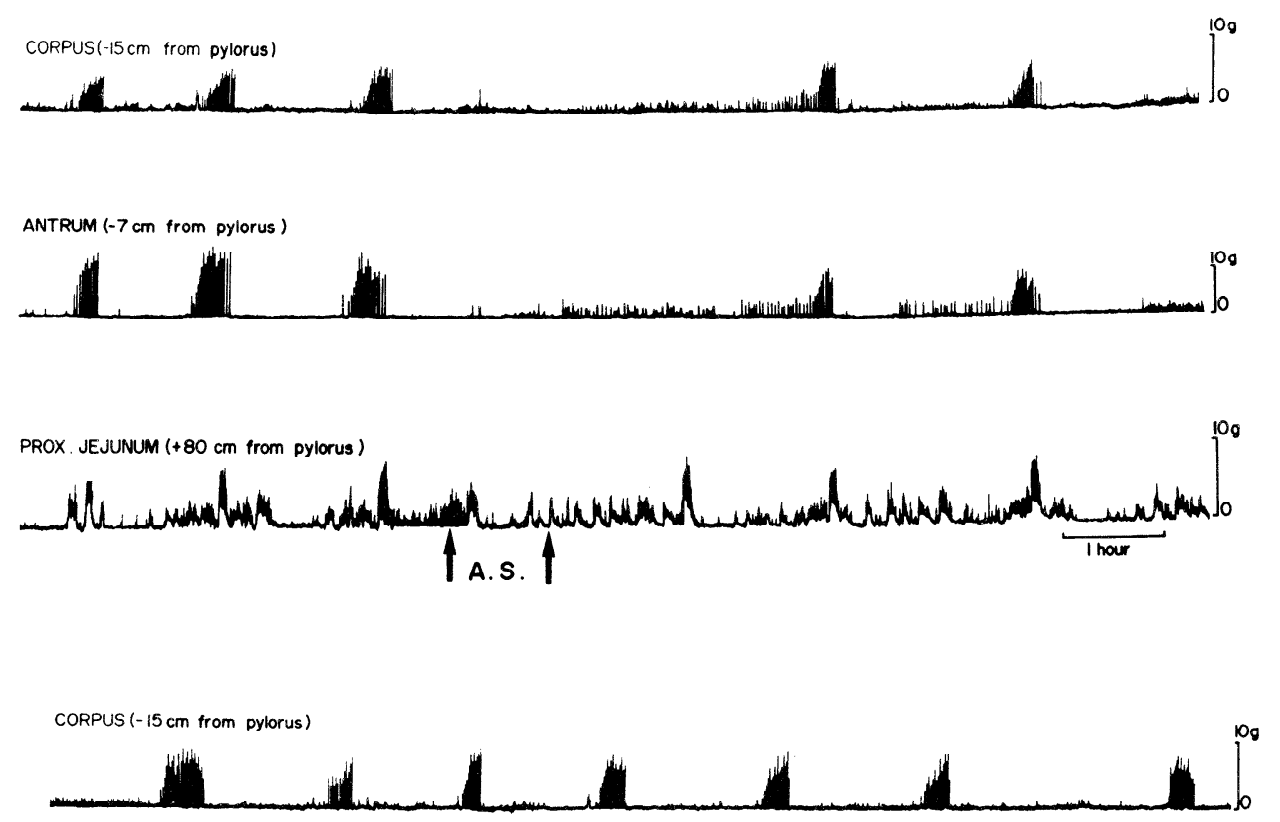

FIG. 1. Influence of acoustic stress (AS) and previous intracerebroventricular (icv) administration of dynorphin$(1-13)$ on gastrointestinal motility in a fasted dog.
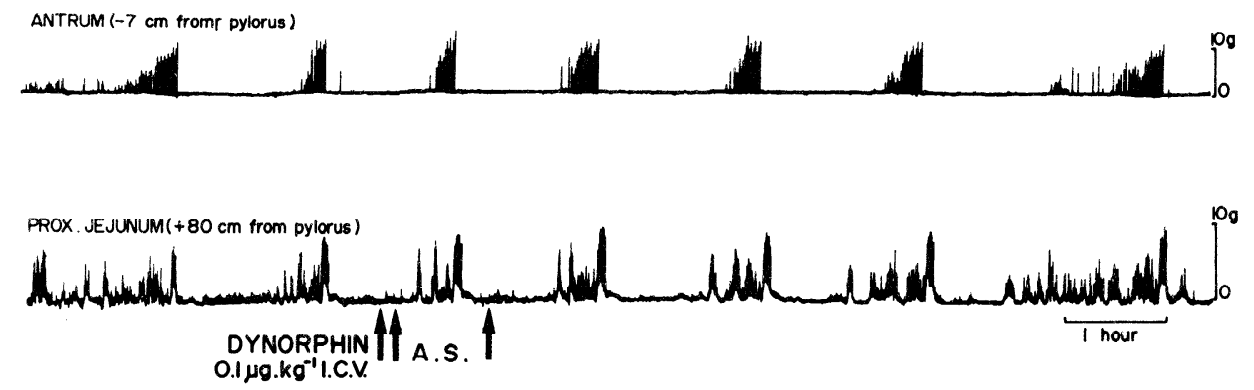

TABLE 1. Comparative influence of dynorphin, EKC, $U$ 50488, and DAGO centrally administered on acoustic stress-induced lengthening of duration of gastric MMC cycle in fasted dogs

\begin{tabular}{lccc}
\hline \hline & & \multicolumn{2}{c}{$\begin{array}{c}\text { Duration of Gastric } \\
\text { MMC Cycle, min }\end{array}$} \\
\cline { 3 - 4 } & Dose, ng/kg & Control & $\begin{array}{c}\text { Acoustic } \\
\text { stress }\end{array}$ \\
\hline Vehicle & & $76 \pm 36$ & $189 \pm 46^{*}$ \\
Dynorphin-(1-13) & 10 & $89 \pm 10$ & $146 \pm 31^{*}$ \\
& 20 & $111 \pm 24 \dagger$ & $88 \pm 27 \dagger$ \\
& 50 & $84 \pm 21$ & $92 \pm 29$ \\
EKC & 100 & $106 \pm 13$ & $101 \pm 16$ \\
& 200 & $207 \pm 37^{*}$ & \\
U 50488 & 10 & $86 \pm 17$ & $91 \pm 13 \dagger$ \\
DAGO & 20 & $110 \pm 31$ & $108 \pm 12 \dagger$ \\
& 50 & $244 \pm 49 \dagger$ & \\
& 20 & $104 \pm 16$ & $105 \pm 16 \dagger$ \\
& 20 & $108 \pm 17$ & $199 \pm 44^{*}$ \\
& 100 & $111 \pm 18$ & $176 \pm 29^{*}$ \\
& 200 & $269 \pm 34 \dagger$ & \\
& & &
\end{tabular}

Values are means \pm SE for 6 dogs. Administrations were done intracerebroventricularly. See text for definition of abbreviations. ${ }^{*}$, + Significantly $(P<0.05)$ different from corresponding control or vehicle values, respectively.

$74.8 \%$ the maximal increase in plasma cortisol level induced by AS (Fig. 2). A significant reduction of the plasma cortisol response to AS was also observed at a lower dose $(50 \mathrm{ng} / \mathrm{kg})$ of dynorphin-(1-13) injected in- tracerebroventricularly $(P<0.01)$. At these two doses (50 and $100 \mathrm{ng} / \mathrm{kg}$ ) dynorphin had no effect per se on basal plasma cortisol level.

Similarly, EKC injected intracerebroventricularly at doses of 10 and $20 \mathrm{ng} / \mathrm{kg}$ had no effect on basal plasma cortisol levels during at least $60 \mathrm{~min}$ but significantly $(P$ $<0.05$ ) reduced by 72.1 and $45.2 \%$ the maximum increase of plasma cortisol induced by AS (Fig. 2). In contrast, DAGO centrally administered at a dose of $100 \mathrm{ng} / \mathrm{kg}$ intracerebroventricularly was unable to reduce significantly $(P>0.05)$ the plasma cortisol increase induced by AS $(41.1 \pm 5.4$ vs. $36.9 \pm 8.1 \mathrm{ng} / \mathrm{ml})$.

$\mathrm{ACTH}(5 \mathrm{IU} / \mathrm{kg})$ injected intravenously $10 \mathrm{~min}$ after previous intracerebroventricular vehicle (control) administration produced an increase in plasma cortisol that reached $80.7 \pm 4.1 \mathrm{ng} / \mathrm{ml}(n=8)$ at $t=90 \mathrm{~min}$, the basal value being $13.1 \pm 2.1 \mathrm{ng} / \mathrm{ml}$. These values were not significantly affected when ACTH injection was preceded (10 $\mathrm{min})$ by intracerebroventricular administration of dynorphin $(50 \mathrm{ng} / \mathrm{kg})$ and EKC $(20 \mathrm{ng} / \mathrm{kg})$ in place of vehicle (Table 2).

Influence of EKC and U 50488 on CRF-induced gastric motor inhibition. As previously described (5) and similar to AS, ovine CRF administered intracerebroventricularly at a dose of $100 \mathrm{ng} / \mathrm{kg}$ in $17-\mathrm{h}$ fasted dogs immediately abolished the cyclic MMC of the stomach during $213 \pm$ 46 min, replacing the cyclic MMC with irregular contractions of very small amplitude, whereas the jejunal 


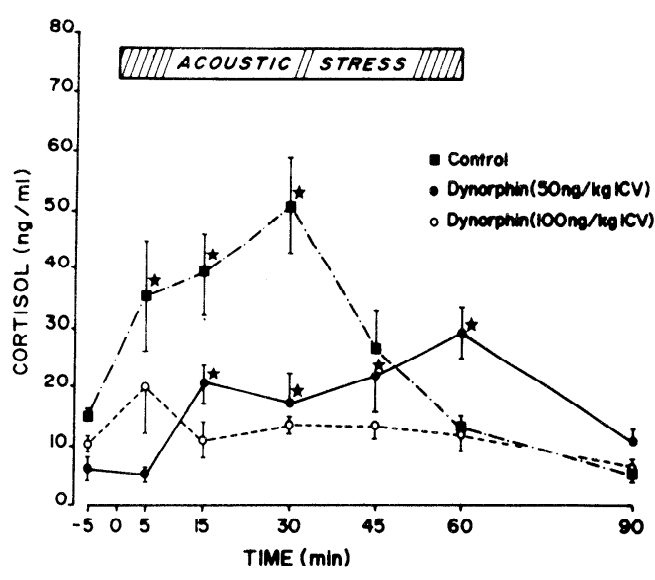

TABLE 2. Influence of central administration of dynorphin-(1-13) and EKC on time-related plasma cortisol increase following intravenous administration of ACTH in dogs

\begin{tabular}{lcccc}
\hline \hline & \multicolumn{5}{c}{ Time After 5 IU/kg ACTH, min } \\
\cline { 2 - 5 } & 0 & 10 & 30 & 90 \\
\hline & \multicolumn{4}{c}{ Plasma cortisol, $\mathrm{ng} / \mathrm{ml}$} \\
$\quad \begin{array}{c}\text { Vehicle } \\
(0.2 \mathrm{ml} \mathrm{icv})\end{array}$ & $13.1 \pm 2.1$ & $63.2 \pm 1.2$ & $82.4 \pm 2.7$ & $80.7 \pm 4.1$ \\
$\begin{array}{c}\text { Dynorphin } \\
(100 \mathrm{ng} / \mathrm{kg} \mathrm{icv})\end{array}$ & $15.8 \pm 4.8$ & $51.3 \pm 3.1^{*}$ & $79.0 \pm 3.3$ & $81.7 \pm 2.7$ \\
$\begin{array}{c}\text { EKC } \\
(20 \mathrm{ng} / \mathrm{kg} \mathrm{icv})\end{array}$ & $12.5 \pm 5.3$ & $63.6 \pm 1.7$ & $85.8 \pm 5.2$ & $77.1 \pm 5.1$ \\
\hline
\end{tabular}

Values are means \pm SE for 8 dogs. See text for definition of abbreviations. * Significantly different $(P \leq 0.05)$ from corresponding control values.

MMCs were unaffected. Both EKC (50 ng/ $\mathrm{kg})$ and U $50488(20 \mathrm{ng} / \mathrm{kg}$ ) administered $10 \mathrm{~min}$ before ovine CRF were unable to affect the duration of its inhibitory effect on gastric MMC (Table 3).

\section{DISCUSSION}

These results confirm previous data showing that AS selectively inhibits gastric motility and increases plasma cortisol levels in the fasted dog (18). They also indicate that effects of AS on gastric motility and cortisol levels are blocked by central administration of $\kappa$ - but not $\mu$ opioid agonists.

These results contrast with previous studies in humans showing that the inhibition of antral postprandial activity induced by stressful stimuli is prevented by a concomitant infusion of the opiate antagonist naloxone (36). However, naloxone is unable to reduce or suppress the AS-induced gastric hypomotility in dogs (20).

Blockade of the AS induced hypomotility and associated cortisol release by diazepam and muscimol (18), and the similarity with the effects of centrally administered CRF (5) have led us to speculate that CRF release is involved in the central mediation of AS-induced inhibition of gastric motility. Consequently it may be postulated that $\kappa$-opioid agonists affect the release of CRF or the pathways involved in the effect of stress.

Numerous studies have demonstrated that endogenous peptides are implicated in CNS control of the release of pituitary hormones $(15,29,35)$. Dynorphin is widely distributed throughout the brain $(21,26)$ with high concentrations found in the hypothalamus and the pituitary $(30,32)$. Recently it has been demonstrated that dynorphin, an endogenous ligand for $\kappa$-receptors (7), has selective opioid effects on the secretion of anterior pituitary hormones (17) and on feeding behavior $(2,23)$. By use of a hypothalamic perfusion system it has been shown in vitro that dynorphin- $(1-13)$ reduces the release of CRF from rat hypothalamus, an effect only partly blocked by naloxone (42). The similarity between the antagonistic action of dynorphin-(1-13) and EKC on AS-induced gastric motor inhibition and cortisol release suggests the selective involvement of $\kappa$-receptors.

Acute stress induces an activation of central muscarinic systems with an ability to activate adrenergic networks responsible for most of the behavioral and neuroendocrine responses to stress $(24,25)$. Consequently $\kappa$ agonists may antagonize the effects of AS by reducing the stress-induced increases in central cholinergic activity. In agreement with this hypothesis, it has been shown that opioid drugs, particularly $\kappa$-agonists, are able to reduce central cholinergic activity $(8,9)$. However, this involvement of $\kappa$-opioids could occurs at least at three levels: 1) an action of the CNS on the adrenal gland through extra hypothalamopituitary pathways, 2) a negative influence on CRF-induced neuronal firing responsible for gastric motor inhibition, or 3) at higher levels by inhibiting stress-induced CRF release.

The gastric motor effects of centrally administered

TABLE 3. Comparative influence of EKC and U 50488 centrally administered on ovine $C R F$-induced inhibition of gastric MMC cycle in dogs

\begin{tabular}{lcc}
\hline \hline & \multicolumn{2}{c}{$\begin{array}{c}\text { Duration of Gastric MMC } \\
\text { Cycle, min }\end{array}$} \\
\cline { 2 - 3 } & Control & $\begin{array}{c}\text { Ovine CRF } \\
(100 \mathrm{ng} / \mathrm{kg} \\
\mathrm{icv})\end{array}$ \\
\hline Vehicle & $76 \pm 36$ & $213 \pm 46^{*}$ \\
EKC & $86 \pm 17$ & $192 \pm 45^{*}$ \\
$(50 \mathrm{ng} / \mathrm{kg} \mathrm{icv})$ & $104 \pm 16$ & $220 \pm 38^{*}$ \\
U 50488 & & \\
$(20 \mathrm{ng} / \mathrm{kg}$ icv) & & \\
\hline
\end{tabular}

Values are means $\pm \mathrm{SE}$ for 6 dogs. See text for definition of abbreviations. * Significantly $(P \leq 0.05)$ different from corresponding control values. 
CRF as well as those of AS are abolished after bilateral vagotomy (20) as are other digestive effects of centrally administered CRF (37).

The lack of effects of intracerebroventricular dynorphin-(1-13) and EKC on ACTH-induced cortisol release and the lack of involvement of ACTH and cortisol in the mediation of the gastric motor effects induced by central administration of CRF (5) are consistent with the hypothesis that $\kappa$-agonists act either on CRF-induced ACTH release and central muscarinic activation or on CRF release. An inhibition of CRF release is more likely in the light of the lack of antagonistic effects of centrally administered $\kappa$-agonist on $\mathrm{CRF}$-induced gastric motor inhibition.

In rats, only the $\mu$-subtype of receptors has been postulated to be involved in the central control of gut motility (34). In agreement with such a hypothesis, DALAMIDE and DAGO, but not DADLE, are known to affect both gastric and intestinal motility when centrally administered in dogs (6). In the present experiment dynorphin and EKC, at least in dogs, were able to affect gastric motility selectively when centrally administered, whereas they were inactive by the systemic route (14). Our findings have also shown that $\kappa$-agonists may exert selective centrally mediated effects on other physiological functions (3), for example by blocking the rat bombesin scratch test while $\mu$ - and $\delta$-selective agonists are inactive (10).

In summary, the present work indicates that $\kappa$-agonists may exert centrally mediated inhibitory effects on ASinduced gastric motor alterations and cortisol release by inhibiting the CNS release of CRF, but the mechanism involved remains partly unknown and requires further investigations.

The authors acknowledge the expert technical assistance of G. Bories and C. Betoulieres and the secretarial assistance of C. Santamaria.

This research was supported by the Institut National de la Recherche Agronomique and by Jouveinal Laboratories.

Received 28 July 1987; accepted in final form 7 January 1988.

\section{REFERENCES}

1. Alvinerie, M., AND P. L. Toutain. Simultaneous determination of corticosterone, hydrocortisone and dexamethasone in dog plasma using high performance liquid chromatography. J. Pharmacol. Sci. 71: 816-818, 1982.

2. Baile, C. A., D. A. Keim, M. A. Della-Ferra, and C. L. MCLAUGHLIN. Opiate antagonists and agonists and feeding in sheep. Physiol. Behav. 26: 1019-1023, 1981.

3. Baskin, D. S., Y. Hosobushi, H. H. Loh, and N. M. I.FF. Dynorphin $(1-13)$ improves survival in cats with focal cerebral ischaemia. Nature Lond. 313: 551-552, 1984.

4. BUCKINGHAM, J. C. Secretion of corticotropin and its hypothalamic releasing factor in response to morphine and opioid peptides. Neuroendocrinology 35: 111-116, 1982.

5. Bueno, L., M. J. Fargeas, M. Gue, 'T. L. Peeters, V. Bormans, AND J. FIORAMONTI. Effects of corticotropin releasing factor on plasma motilin and somatostatin levels and gastrointestinal motility in dogs. Gastroenterology 91: 884-889, 1986.

6. Bueno, L., J. Hioramonti, C. Honde, M. J. Fargeas, and M. P. PRIMI. Central and peripheral control of gastrointestinal and colonic motility by endogenous opiates in conscious dogs. Gastroenterology 88: 549-556, 1985.

7. Chavkin, C., I. F. James, ANd A. Goldstein. Dynorphin is a specific endogenous ligand of the kappa opioid receptor. Science Wash. DC 215: 413-415, 1982.

8. Cheney, D. L., M. Trabucchi, G. Racagni, C. Wang, and E. Costa. Effect of acute and chronic morphine on regional rat brain acetylcholine turnover rate. Life Sci. 15: 1977-1990, 1974.

9. Christie, M. J., ANv D. H. OverstreET. Sensitivity of morphinetolerant rats to muscarinic and dopaminergic agonists: relation to tolerance or withdrawal. Psychopharmacology 65: 27-34, 1979.

10. CoWAN, A., AND D. E. GMEREK. In vivo studies on kappa opioid receptors. Trends Pharmacol. Sci. 7: 69-72, 1986.

11. Del Pozo, E., J. Martin-Perez, A. Stadelmann, J. Girard, AND J. BROWNELL. Inhibitory action of a met-enkephalin on ACTH release in man. J. Clin. Invest. 65: 1531 1534, 1980.

12. De Souza, E. B., AND G. R. Van Loon. D-Ala-Met-enkephalinamide, a potent opioid peptide, alters pituitary-adrenocortical secretion in rats. Endocrinology 111: 1483-1490, 1982.

13. EISENBERG, R. M. Effects of naltrexone on plasma corticosterone in opiate-naive rats: a central action. Life Sci. 34: 1185-1191, 1984.

14. Fioramonti, J., M. J. Fargeas, and L. Bueno. Comparative effects of morphine and cyclazocine on gastrointestinal motility in conscious dogs. Arch. Int. Pharmacodyn. Ther. 270: 141-150, 1984.

15. Gilbeau, P. M., R. G. Almirez, J. W. Holaday, and C. G. SMITH. Opioid effects on plasma concentrations of luteinizing hormone and prolactin in the adult male rhesus monkey. J. Clin. Endocrinol. Metab. 60: 299-305, 1985.

16. Gilbeau, P. M., Y. Hosobuchi, and N. M. Lee. Dynorphin effects on plasma concentrations of anterior pituitary hormones in the non human primate. J. Pharmacol. Exp. Ther. 238: 944-977, 1986.

17. Grossman, A., R. C. Gaillard, P. McCartney, L. H. Rees, and G. M. BESSER. Opiate modulation of the pituitary adrenal axis: effects of stress and circadian rhythm. Clin. Endocrinol. 17: 279$286,1982$.

18. Gue, M., AND L. BuENo. Diazepam and muscimol blockade of the gastrointestinal motor disturbances induced by acoustic stress in dogs. Eur. J. Pharmacol. 131: 123-127, 1986.

19. Gue, M., J. Fioramonti, and L. Bueno. Comparative influence of acoustic and cold stress on gastrointestinal transit in mice. Am. J. Physiol. 253 (Gastrointest. Liver Physiol. 16): G124-G128, 1987.

20. Gue. M., J. Fioramonti, J. Frexinos, M. Alvinerie, and L. BUENO. Influence of acoustic stress by noise on gastrointestinal motility in dogs. Dig. Dis. Sci. 32: 1611-1617, 1987.

21. Hokfelt, V., I. HaArman, K. Bovermann, M. Jerlicz, and A. HERz. Dynorphin-related immunoreactive peptides in rat brain. Neurosci. Lett. 18: 149-153, 1980.

22. IYENGAR, S., H. S. KIM, AND P. L. Wood. Kappa opiate agonists modulate the hypothalamic-pituitary-adrenocortical axis in the rat. J. Pharmacol. Exp. Ther. 238: 429-436, 1986.

23. JACKSON, A., AND S. J. Cooper. The involvement of the kappa opiate receptor in the control of food intake in the rat. Neuropharmacology 25: 653-654, 1986.

24. Janowsky, D. S., S. C. Risch, L. Huey, L. Judd, And J. Rousch. Central physostigmine-induced cardiovascular and behavioral changes: toward an acetylcholine hypothesis of stress. Psychopharmacol. Bull. 19: 675-682, 1983.

25. Janowsky, D. S., S. C. Risch, ANd M. Ziegler. Central acetylcholine in stress and affective disorders. Clin. Neuropharmacol. 7, Suppl. 1: 958-959, 1984.

26. Khachaturian, H., M. E. Lewis, M. K. H. Schafer, and S. J. Watson. Anatomy of the CNS opioid systems. Trends Neurosci. 8: 111-119, 1985.

27. Lewis, J. W., J. E. Sherman, AND J. C. Lieheskind. Opioid and non-opioid stress analgesia: assessment of tolerance and crosstolerance with morphine. J. Neurosci. 1: 358-363, 1981.

28. Lynch, W. C., J. Watt, S. Krall, and C. M. Paden. Autoradiographic localization of kappa opiate receptors in CNS taste and feeding areas. Pharmacol. Biochem. Behav. 22: 699-705, 1985.

29. Morley, J. E., M. L. Willenbring, D. D. Krahn, G. A. Carlson, J. E. Briggs, A. S. Levine, and R. B. Shafer. Opioid control of thyroid function. In: Opioid Modulation of Endocrine Function, edited by G. Delitala, M. Motta, and M. Serio. New York: Raven, 1984, p. 267-275.

30. NakaO, K., T. Yoshimasa, S. OKI, I. Tanaka, Y. Nakai, M. Wakimasu, M. Fujino, and H. Imura. Presence of dynorphinlike immunoreactivity in rat pituitary gland and hypothalamus. Regul. Pept. 2: 201-208, 1981.

31. Nakasinma, H., Y. Hirata, M. Uchihashi, T. Fujita, H. Tani- 
GUCHI, S. BABA, AND S. MATSUKURA. Concomitant suppression of plasma ACTH and $\beta$-endorphin-like immunoreactivity by cyproheptadine, naloxone and somatostatin in the ectopic ACTH syndrome. Horm. Metab. Res. 17: 205-208, 1987.

32. Pascaud, X., M. J. Genton, AND P. Bass. A miniature transducer for recording intestinal motility in unrestrained chronic rats. $A m$. J. Physiol. 235 (Endocrinol. Metab. Gastrointest. Physiol. 4): E532E539, 1978.

33. Plotsky, P. M. Opioid inhibition of immunoreactive corticotropin-releasing factor secretion into the hypophysial-portal circulation of rats. Regul. Pept. 16: 235-242, 1986.

34. Porreca, F., J. J. Galligan, and T. F. Burks. Central opioid receptor involvement in gastrointestinal motility. Trends Pharmacol. Sci. 7: 104-107, 1986.

35. Ropert, J. F., M. E. QUigley, AND S. S. C. Yen. Endogenous opiates modulate pulsatile luteinizing hormone release in humans. J. Clin. Endocrinol. Metab. 52: 583-587, 1981.

36. Stanghellini, V., J. R. Malagelada, A. R. Zinsmeister, V. L. M. Go, AND P. C. KAO. Effect of opiate and adrenergic blockers on the gut motor response to centrally acting stimuli (Abstract). Gastroenterology 87: 1104-1113, 1984.

37. Tache, Y., Y. Goto, M. Gunion, J. Rivier, and M. Brown. Inhibition of gastric acid secretion in rats and dogs by intracerebral injection of corticotropin releasing factor. Science Wash. DC 222: 935-937, 1983.

38. Thompson, D. G., E. Richelson, and J. R. Malagelada. Perturbation of upper gastrointestinal function by cold stress. Gut 24 : 277-281, 1983.

39. Willer, J. C., H. Dehen, and J. Cambien. Stress-induced analgesia in humans: endogenous opioids and naloxone-reversible depression of pain reflexes. Science Wash. DC 212: 689-691, 1981.

40. Yajima, F., T. Suda, N. Tomori, S. Takashi, Y. Nakagami, T. Ushiyama, H. Demura, and K. Shizume. Effects of opioid peptides on immunoreactive corticotropin releasing factor release from the rat hypothalamus in vitro. Life Sci. 39: 181-186, 1986.

41. Zis, A. P., R. F. Haskett, A. A. Albala, and B. J. Carroll. Morphine inhibits cortisol and stimulates prolactin secretion in man. Psychoneuroendocrinology 9: 423-427, 1984.

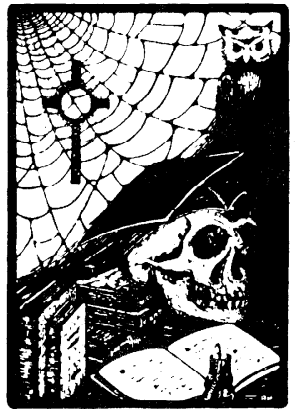

